\title{
The Large Society Problem in Northwest Europe and East Asia
}

\author{
Peter Frost \\ Department of Anthropology, Université Laval, Quebec, Canada \\ Email: peter_frost61z@globetrotter.qc.ca
}

How to cite this paper: Frost, P. (2020). The Large Society Problem in Northwest Europe and East Asia. Advances in Anthropology, 10, 214-234. https://doi.org/10.4236/aa.2020.103012

Received: May 22, 2020

Accepted: August 4, 2020

Published: August 7, 2020

Copyright $\odot 2020$ by author(s) and Scientific Research Publishing Inc. This work is licensed under the Creative Commons Attribution International License (CC BY 4.0).

http://creativecommons.org/licenses/by/4.0/ (c) (i) Open Access

\begin{abstract}
Kinship was the organizing principle of early societies, defining how people should behave toward each other. Social and economic activity was thus organized mostly among closely related individuals, a limitation that would keep societies from realizing their full potential as they grew larger. The "large society problem" has not been fully solved anywhere, but Northwest Europeans and East Asians have gone the farthest toward a solution. In general, the solution has been to weaken the relative importance of kinship and strengthen forms of sociality that can include everyone, and not just close kin. In particular, one must think and feel in certain ways, i.e., be susceptible to social norms that are absolute, universal, and independent of kinship; feel guilty after breaking social norms; feel empathy for non-kin; and orient oneself toward society. This mindset shows similarities and differences between Northwest Europeans and East Asians. Both groups adapted to a larger social environment by becoming more empathetic toward non-kin and more susceptible to universal social norms. Northwest Europeans became more individualistic while acquiring stronger internal controls of behavior (affective empathy, guilt proneness). East Asians became more collectivistic while acquiring stronger internal controls (cognitive empathy) and stronger external controls (shaming, family-community surveillance, inculcation of normative behavior).
\end{abstract}

\section{Keywords}

Affective Empathy, Cognitive Empathy, Guilt Proneness, Collectivism, Individualism, East Asians, Northwest Europeans

\section{Introduction}

Kinship was the organizing principle of early societies, either bands of hunter-gatherers or small farming villages. It defined how people should behave to- 
ward each other. Thus, what was wrong toward kin could be right toward non-kin, or at least not punishable. To enforce these social norms, kin would punish wrong behavior through ridicule, shaming, ostracism, and lynching, while rewarding right behavior with praise and increased trust.

This point was made by English anthropologist Alfred Radcliffe-Brown with respect to Africa:

For the understanding of any aspect of the social life of an African people-economic, political, or religious, it is essential to have a thorough knowledge of their system of kinship and marriage. This is so obvious to any field anthropologist that it hardly needs to be stated (Radcliffe-Brown, 1987 [1950]: p. 1).

In such societies, kinship defines how people should behave toward each other: "But the actual behaviour of two persons in a certain relationship (father and son, husband and wife, or mother's brother and sister's son) varies from one particular instance to another" (Radcliffe-Brown, 1987 [1950]: p. 10). The rightness or wrongness of a behavior is thus situational rather than universal, and relative rather than absolute.

As societies grow larger, kinship ties become a less effective means to deal with wrong behavior. The victim's family cannot use them to bring pressure to bear on the wrongdoer if he or she is unrelated. Retaliation is possible, but the wrongdoer's family will likely counter-retaliate, the result being a vendetta that may last indefinitely and cause much more harm than the initial wrong. So a peaceful alternative is needed; hence the State monopoly on violence (Frost, 2010; Frost \& Harpending, 2015); hence the codification of law and the establishment of courts.

In much of the world, that is as far as cultural evolution has gone. Large societies are generally peaceful, but the sphere of trust extends no farther than close kin. For people farther out, agreements must be enforced by the threat of nonviolent retaliation or legal prosecution, the latter often being expensive, time-consuming, and not always impartial. Social and economic activity is thus organized mostly within groups of closely related individuals.

In his economic history of India, Gurcharan Das writes: "Perhaps this is why our streets are dirty when our homes are spotlessly clean" (Das, 2002: p. 81). Seeing loyalty to kin as an obstacle to development, in a country of family-owned and family-run businesses, he argues that a market economy cannot fully develop without trust between strangers:

Where strangers spontaneously trust each other and cooperate with each other, there is high social capital. Indeed, Tocqueville regarded this "art of association" as an essential virtue of American society because it moderated the American tendency towards individualism. Trust and cooperation are necessary in all market activity. Social capital can help companies make the transition from small family units to large, professionally run enterprises. 
High trust can dramatically lower transaction costs, corruption, and bureaucracy (Das, 2002: pp. 267-268).

\section{Solving the "Large Society Problem"}

If a large society is to realize its full potential, the sphere of trust must expand beyond close kin (Rose, 2019). How can this be done? How can trusting relationships become usual and expectable in a society that encompasses so many people?

This problem has not been fully solved anywhere, but Northwest Europeans and East Asians have gone the farthest toward a solution. In general, the solution has been to weaken the relative importance of kinship and strengthen forms of sociality that can include everyone, and not just close kin. In particular, one must think and feel in certain ways:

- be susceptible to social norms that are absolute, universal, and independent of kinship;

- feel guilty after breaking social norms;

- feel empathy for non-kin;

- orient oneself toward society.

The above mindset has arisen through changes to existing susceptibilities, propensities, and orientations that all humans share to some degree. By this means, the genetic basis of a complex behavior can diverge rapidly between two populations, even over as short a time as recorded history (Chen et al., 2016; Cochran \& Harpending, 2009; Hawks et al., 2007). Rapid genetic change happens not through creation of an entirely new set of functionally related genes but through an existing set being regulated in new ways, often via a few point mutations. Thus, a behavior may increase or decrease in intensity. It may also change in its timing or its threshold of stimulation. It may target a different class of persons or objects. It may be expressed in both sexes, instead of only in one, or in adults, instead of only in children (Baker et al., 2001; Harpending \& Cochran, 2002).

A complex behavior is influenced by many loci on the genome. It may therefore evolve through mutations at a large number of genes, each of which has a small effect on the actual behavior. But this is not always the case (we should not extrapolate from the genetic basis of cognitive ability to that of other mental or behavioral traits). In fact, evolutionary change may be confined to a small subset of regulatory genes (Doan et al., 2016). Whatever the number of genes, they have all undergone the same process of selection, and each of them is a witness to that process. Thus, through single-gene studies, we can interrogate these witnesses to determine the strength and direction of selection and find out exactly what has been selected.

We will now discuss each component of the above mindset, first defining it at greater length and then reviewing the literature, i.e., general discussions, heritability studies if they exist, and single-gene studies. 


\subsection{Being Susceptible to Universal Social Norms}

This is the propensity to identify social norms, to comply with them always and in all situations, and to ensure that others do so. Norms are thus seen as having an absolute and universal quality that transcends the situation and its actors. The same applies to norm-breaking. To break a norm is to offend not only a particular person but also a general principle. In time, the principle may be sanctified and divinized, thus becoming even more inviolable. Offenders therefore incur the wrath of the entire community, and not just the victim's family. In sum, behavior is controlled through norms that are enforced internally through faith and externally through community justice (Berman, 1974).

Susceptibility to social norms is influenced by the gene $O X T R$ rs53576. The G allele seems to increase this susceptibility, although the actual norms may differ from one culture to another. Americans with the GG genotype report suppressing their emotions less often than those with other genotypes, whereas Koreans report the reverse (Kim et al., 2011). People with the GG genotype also feel less lonely (Lucht et al., 2009).

A similar gene-culture interaction exists at $D R D 4$. People are made more susceptible to social norms by the $2 \mathrm{R}$ allele or the $7 \mathrm{R}$ allele and less susceptible by the $4 \mathrm{R}$ allele (Sasaki et al., 2013). In the United States, $2 \mathrm{R}$ and $7 \mathrm{R}$ carriers are prone to risk seeking and heavy drinking; in East Asia, they are not (Kitayama et al., 2014). In the United States, $2 \mathrm{R}$ and $7 \mathrm{R}$ carriers are prone to positive emotions rather than negative emotions; in East Asia, they are prone to a balanced mix of positive and negative emotions, this being typical of East Asian cultures (Tompson et al., 2018). Finally, 7R carriers are more hypercompetitive than non-carriers among men, whereas the reverse is true among women (Bircher et al., 2019). To summarize, if people are more susceptible to social norms, their behavior will be more divergent between different environments of socialization, such as those of the United States and East Asia or those of men and women.

The same gene shows an interaction between norm susceptibility and religion, specifically as a support for altruistic behavior. Using American and East Asian participants, Sasaki et al. (2013) found that $2 \mathrm{R}$ and $7 \mathrm{R}$ carriers were more altruistic than non-carriers if previously primed by the task of making a sentence from religious-sounding words. Priming had no effect on non-carriers. These findings were partially replicated by Jiang et al. (2015). Among Chinese Singaporean participants, $2 \mathrm{R}$ carriers were more altruistic than non-carriers among male Christians, while being the same as non-carriers among women, Taoists, and Buddhists. The authors argued that men have more room for improvement because women start off caring more about others. The authors further suggested that Christianity better supports altruism by offering fellowship, comprehensible texts, and regular activities. Thus, if susceptibility to social norms is increased, altruistic behavior will increase if the environment of socialization is Christian.

Other interesting differences exist among the three $D R D 4$ alleles. Although $4 \mathrm{R}$ 
carriers are less susceptible to social norms, they have a greater expectation that everyone should play by the same rules (Zhong et al., 2010). There is thus a stronger commitment to the universality of social norms. In addition, the level of altruism seems to be lower in $7 \mathrm{R}$ carriers than in $2 \mathrm{R}$ or $4 \mathrm{R}$ carriers (Anacker et al., 2013).

Commitment to universal social norms includes honesty. This is the desire to tell the truth in all situations, as opposed to altering the "truth" to suit the circumstances. Honesty seems moderately heritable, according to familial and twin studies (Ahern et al., 1982; Eaves et al., 1999; Loewen et al., 2013; Young et al., 1980). Undoubtedly, the heritable component involves many loci on the genome. One is $T P H 2$, whose alleles influence individual differences in deceptive behavior, perhaps by changing the balance between attention to current stimuli and attention to long-term consequences (Shen et al., 2016). Another is GABRA2 rs279858, whose alleles interact with sex to influence the propensity to lie (Luman, 2019).

Commitment to universal social norms may also include moral elevation. This is the positive emotion you feel when witnessing or hearing about a virtuous act, regardless of who does it. In other words, it is the tendency to admire virtuous people and thus act virtuously oneself. The same neural circuits seem to be used as with cognitive empathy-the ability to make inferences about another person's mental state (Englander et al., 2012).

Social norms probably became independent of kinship during the existence of our species, if only because this process remains unfinished in most human groups. Nonetheless, some biologists, notably Robert Trivers, argue that universal social norms have developed in some animals through reciprocal altruism: an animal behaves altruistically while expecting to be reciprocated, and to this end it identifies and punishes "cheaters" who take but do not give. Trivers believes that "friendship, dislike, moralistic aggression, gratitude, sympathy, trust, suspicion, trustworthiness, aspects of guilt, and some forms of dishonesty and hypocrisy can be explained as important adaptations to regulate the altruistic system" (Trivers, 1971). His theory is still controversial, mainly because reciprocal altruism is often difficult to distinguish from altruism toward kin.

\subsection{Feeling Guilty after Breaking Social Norms}

This is an internal control of behavior. It activates even when you are the sole witness to your wrongdoing or have simply imagined your wrongdoing. Thoughts and behavior are self-monitored with a view to self-judgment and self-punishment. Such punishment can be severe, taking the form of depression, rumination, and self-hatred. The severity will depend not only on the wrongdoing itself but also on the possibility of lifting the burden of guilt, typically through confession and atonement. If the burden cannot be lifted, self-punishment may last indefinitely; for instance, if the wronged person has died (Bybee et al., 1996). In such cases, a possible solution is indirect reparation: religious confes- 
sion and penance, restitution to the deceased person's family, charity in honor of the deceased, etc. (Bybee \& Quiles, 1998).

Guilt proneness shows high heritability between families (Cattell et al., 1981). According to a twin study, displays of guilt are significantly heritable at 14 months but not at 20 and 24 months (Zahn-Waxler \& Robinson, 1995). Heritable influences may activate during certain stages of life, as suggested by a finding that guilt proneness correlates with intensity of early adolescent trauma in carriers of the low-expressing Met allele of BDNF Val66Met (Szentágotai-Tatar et al., 2015).

Males are less prone to chronic guilt and feel guilty with decreasing intensity as they go through adolescence. Females are more prone and have more trouble getting over guilt (Bybee, 1998). A meta-study concluded that sex differences are negligible in childhood but small to medium in adolescence (Else-Quest et al., 2012).

Guilt proneness is closely linked to affective empathy, and the two apparently share many of the same neural circuits, notably for recognition of facial emotions (Treeby et al., 2016). Feelings of guilt seem to be especially triggered by facial expressions of sadness, anger, fear, or disgust (Prado et al., 2017). Although guilt superficially resembles shame, the two show opposing associations with affective empathy and other mental traits (Tangney et al., 1992; Tangney et al., 2011).

\subsection{Feeling Empathy for Non-Kin}

This trait comes in two forms. Cognitive empathy is the ability to understand how others feel, whereas affective (or emotional) empathy is the ability to internalize those feelings and actually feel another person's pain or joy. The two forms are mediated by different neural circuits. Affective empathy simultaneously controls the emotions and their associated responses, whereas cognitive empathy is less automatic and controls responses much more through mentalizing (Christov-Moore et al., 2014). Both forms are generally triggered by human targets, especially faces and individuals in social situations, but other targets are possible. Treatment with oxytocin, which enhances social emotions, increases empathic response to inanimate targets, especially human-looking ones (Peled-Avron et al., 2016).

Affective empathy is $52-57 \%$ heritable, and cognitive empathy $27 \%$ heritable (Melchers et al., 2016; cf. also Chakrabarti \& Baron-Cohen, 2013). This is in line with longitudinal studies on children: affective empathy remains stable as a child develops, while cognitive empathy gradually increases, perhaps through learning (Decety et al., 2017).

Both forms of empathy show sex differences. Affective empathy is stronger in women than in men (Baez et al., 2017; Baron-Cohen \& Wheelwright, 2004; Hoffman, 1977; Liu et al., 2018; Toccaceli et al., 2018). This sex difference largely explains why women are less aggressive and more likely to forgive and feel grateful (Dryburgh \& Vachon, 2019; Witvliet et al, 2019; Witvliet et al., 2020). Cognitive 
empathy is also stronger in women than in men, but the difference is small (Vellante et al., 2013; Weisman et al., 2015). A review of the literature concluded: "In general, although there do appear to be sex differences in cognitive empathy, females do not appear to show the same obvious advantage over males, as they do with affective empathy, which may indicate that these systems are somewhat independent" (Christov-Moore et al., 2014). In a controlled study, cognitive empathy was significantly reduced in young women who had received testosterone. Interestingly, the reduction was limited to those who had experienced high levels of testosterone in the womb, as inferred from their 2D:4D ratios. It was absent in women who had experienced low levels (van Honk et al., 2011).

The capacity for affective empathy is indicated by certain biological or genetic traits. A brain MRI study showed that altruism toward strangers is associated with a larger amygdala and that this brain region responds more strongly to images of fearful faces. A weaker response, as seen in psychopaths, is associated with a smaller amygdala (Marsh et al., 2014). Two studies, one in southern California and the other in London, found that the amygdala is larger in "conservatives" than in "liberals" (Kanai et al., 2011; Schreiber et al., 2013). The difference may actually be ethnic: in both the United States and the United Kingdom, "conservatives" are overrepresented in the longer-established population.

An $A D R A 2 b$ allele seems to support mental processes upstream to both affective empathy and cognitive empathy. Carriers remember emotional images longer and more vividly, with such images evoking a stronger response in the amygdala (Todd \& Anderson, 2009; Todd et al., 2015). Studies to date have shown a population frequency of $10 \%-20 \%$ in sub-Saharan African groups, $30 \%$ - 65\% in European groups, and 55\% - 75\% in East Asian groups (Belfer et al., 2005; Cousijn et al., 2010; de Quervain et al., 2007; Fridman et al., 2012; Ishii et al., 2015; Mulerova et al., 2015; Small \& Liggett, 2001; Suzuki et al., 2003; Zhang et al., 2005).

Affective empathy has a long evolutionary history as a support for parental care. "Empathetic behavior appears particularly strong in social species with prolonged parental care, such as mammals and some birds, in which there are reports of behaviors that are indicative not only of sensitivity to others' emotional states, but also of the presence of some basic forms of empathy" (Christov-Moore et al., 2014). Affective empathy is so hardwired that little cognitive effort is needed: it is "a fast, stimulus-driven response that aligns the motor behavior of the observer and the observed." One example is "emotional contagion": one person smiles and others immediately follow suit.

The sex difference in affective empathy is likewise evolutionarily old. In mice, rats, and pigs, females appear to be more sensitive than males to the pain of others (Christov-Moore et al., 2014; Langford et al., 2010). In humans, affective empathy may have initially served to help a mother care for her infants. It later became extended to all social relations, but only in some populations. An analogy would be lactose tolerance in our species. The ability to digest lactose is 
usually confined to infants, but adults retain it in populations that have long consumed dairy products.

Cognitive empathy seems evolutionarily recent and less hardwired. Its lower heritability points to a greater role for learning.

\subsection{Orienting Oneself toward Society}

This is how you conceive yourself in relation to others. It may be thought of as a continuum. At one end, the individualist has weak community ties, seeks personal happiness, and does not wish to be like others. At the other end, the collectivist has strong community ties, seeks social happiness, and wishes to be like others. The desire to imitate others seems to be a highly specific mechanism: approximately $62 \%$ of its genetic variance is independent of genetic influences on mental development and temperament (Fenstermacher \& Saudino, 2016).

Social orientation has been linked to several genes. A desire to imitate others is associated with the short allele of 5-HTTLPR, according to a study of American two-year-olds (Schroeder et al., 2016). The same allele has also been linked to anxiety and depression, but these adverse outcomes may be prevented in a collectivistic environment that provides sufficient caring relations and support networks (Caspi et al., 2003; Chiao \& Blizinsky, 2010).

\subsection{Interactions}

The above mental traits can interact with each other. For instance, susceptibility to universal social norms can push you toward either individualism or collectivism, depending on which is normative. This is seen at the DRD4 gene with the $2 \mathrm{R}$ and $7 \mathrm{R}$ alleles, which are associated with increased norm susceptibility. Whereas $2 R$ and $7 R$ carriers are more individualistic than non-carriers among Euro-Americans, the reverse is true among East Asians. Non-carriers have the same social orientation in both groups (Kitayama et al., 2014).

It has been argued that a collectivistic orientation should increase your affective empathy by making you identify more with other people and their feelings: "if self and other are not sharply distinct in a helper's mind, it is not possible to separate egoism from altruism in a helper's motive" (Cialdini et al., 1997, cf. also Burris \& Rempel, 2012). This argument is not supported by population data from $O X T R$ rs53576. The A allele is more frequent in East Asians and associated with collectivism, whereas the G allele is more frequent in Europeans and associated with individualism (Luo \& Han, 2014). Yet the G allele is the one associated with affective empathy, not the A allele, even among Chinese participants taken alone (Luo et al., 2015). This form of empathy is actually more strongly linked to individualism, being perhaps a coevolving trait that makes the latter possible in a social environment with weak kinship ties.

The whole is therefore greater than the sum of its parts. A population adapts to an environment through a package of interacting mental, behavioral, and even ideological traits. Consequently, no single trait can work on its own. It has 
to work in conjunction with others and with a certain environment. In another environment, the same package may perform differently, perhaps better, perhaps worse.

\section{Two Paths}

The above traits have developed to varying degrees in Northwest Europeans and East Asians. There have thus been two paths of evolutionary change whose societal outcomes are similar in some respects and different in others.

Similarities may exist because Northwest Europeans and East Asians are descended from a common ancestral population that occupied northern Eurasia during the Upper Paleolithic (Frost, 2019). Another possible reason is convergent evolution. There are only so many ways to create a large society and make it work over the long term.

Differences may exist because Northwest Europeans and East Asians have adapted to different environments, such as different food sources. In addition, although these two populations share a common origin, they have diverged from each other culturally and genetically, and this divergence may limit convergent evolution. When people are confronted with a new problem, they will solve it as best they can with what they have. Two populations may thus solve it differently because they do not share the same cultural and genetic basis for a solution.

\subsection{Northwest Europeans}

For at least the past millennium, kinship ties have been unusually weak among Europeans north and west of a line running from Trieste to St. Petersburg. Almost everyone is single for at least part of adulthood, and many stay single their entire lives. In addition, children usually leave the nuclear family to form new households, and many individuals circulate among unrelated households, typically young people sent out as servants (Hajnal, 1965; Hartman, 2004; ICA, 2020; Seccombe, 1992: pp. 94-95, 150-153, 184-190). This unusual marital and familial pattern is associated with an equally unusual behavioral pattern: people are more individualistic, less loyal to kin, and more willing to trust strangers (Frost, 2017).

Schulz et al. (2019) ascribed this behavioral pattern to the Western branch of Christianity, particularly its ban on consanguineous marriages and a consequent weakening of family ties and strengthening of impersonal relationships. The ban should therefore predate its presumed effects. Actually, no one knows which came first. As we go farther back in time, we have less data to work with, but the same behavioral pattern still appears in the little we do have. In thirteenth-century Lincolnshire, households were already nuclear and the age of first marriage was typically late: 24 for the woman and 32 for the man (Hallam, 1985: p. 66). In ninth-century France, households were small and nuclear among married people, $12 \%$ to $16 \%$ of adults were unmarried, and both sexes married in their mid to late twenties (Hallam, 1985: p. 56; Seccombe, 1992: p. 94). Earlier data do not permit firm conclusions, being too fragmentary and usually focused on elite 
males with young brides. Nonetheless, we see evidence of first marriages at late ages, such as observations by Julius Caesar and Tacitus that people in the Germanic tribes married late (Caesar, 1915: De Bello Gallico 6: 21; Tacitus, 1970: Germania 20).

So the causality may run in the opposite direction. In other words, Northwest Europeans do not behave differently because the Western Church banned consanguineous marriages whereas the Eastern Church did not; instead, the Western Church assimilated the social norms of its Northwest European converts. The second hypothesis is backed by the timeline. Roman Civil Law had banned only first-cousin marriages, and the first legal code to go farther was the mid-seventh century Visigothic Code, which went two degrees farther (McCann, 2010: p. 57). In the early ninth century, the Western Church began to calculate degrees of kinship differently by adopting the Germanic system. Previously, under the Roman system, first cousins had been considered fourth degree. The new system made them second degree, thereby doubling the number of forbidden marriage partners (McCann, 2010: pp. 57-58). In sum, the ban was Church-enforced but ultimately came from a Germanic source.

The same source may explain other differences between the two branches of Christianity. Why, for instance, is the doctrine of original sin and hereditary guilt more developed in the Western Church? One reason may have been that the converted peoples tended to regulate their behavior by internal means-by feeling guilty over wrongdoing, instead of being shamed by others. In the guilt cultures of Northwest Europe, a person would feel guilty until the wrongdoing was undone or redressed, an outcome not always possible. The resulting burden of guilt had to be regularly purged somehow, and the Western Church became oriented to that end (Frost, 2017).

The Western Church thus assimilated a pre-existing pattern of weak kinship, late marriage, individualism, and openness to non-kin. This behavioral pattern was in turn supported by certain mental traits: capacity for involuntary guilt and empathy, especially affective empathy; susceptibility to absolute and universal social norms, as opposed to situational norms based on kinship; and desire to punish, exclude, and even kill norm-breakers (Frost, 2017). The result was to extend interpersonal trust far beyond close kin, thereby enabling social and economic relations that would otherwise be impossible (Medrano, 2010).

Thus, long before the modern era, and apparently even before Christianity, Northwest Europeans had a mindset that could exploit the possibilities of a large society, including some that appeared much later with the growth of the State, with the expansion of guilt culture through Christianity, with the pacification of social relations, and with the reorganization of those relations independently of kinship-through the market economy and the nation state.

If Christianity did not create that mindset, what did? If we go farther back in time within Northwest Europe, particularly the core area of the North Sea and Baltic littoral, we come to an unusual culture: the fisher-hunter-gatherers of the 
late Mesolithic, i.e., 8500 to 6000 years ago and later in some areas. Their societies were more complex and more densely populated than those of other hunter-gatherers, thanks to an abundant food supply of fish, seals, and shellfish (Price, 1991; Zvelebil \& Dolukhanov, 1991). They lived from spring to fall in large coastal communities and had to deal with the large society problem at an early date, long before the coming of agriculture.

Those coastal communities were unusual not only in their size and seasonality but also in the tendency of nuclear families to live together in large multi-unit dwellings (Grøn, 2003). This degree of inter-familial intimacy had been absent during the early Mesolithic and would remain rare among hunter-gatherers elsewhere. For Grøn (2003), it was caused not by a new natural environment but by a new cultural environment-a kind of Neolithic before the Neolithic. Such a milieu, with neither farming nor year-round sedentary living, may have led to a unique solution to the large society problem.

Many of the above points have been made by Kevin MacDonald (2019a, $2019 b)$. He rightly views this pattern of individualism and weak kinship in terms of clinal variation, i.e., it is strongest in the northwest of Europe and progressively weaker farther south and east. While acknowledging the role of the Western Church in promoting this behavioral pattern, he points out that the Church authorities were building on pre-existing tendencies.

\subsection{East Asians}

East Asians have followed a different path to a similar end, relying less on internal control of behavior (affective empathy, guilt proneness) and more on external control (shaming, family-community surveillance) (Bedford \& Hwang, 2003; Lebra, 1971). External control is also internalized through inculcation of normative behavior, such as appropriate ways of greeting, sitting, eating, and even sleeping (Tan, 2017). Unlike Northwest Europeans, East Asians still have strong kinship ties and are actually less individualistic than humans in general. Whereas a greater sense of self has helped Northwest Europeans transcend the limitations of kinship and build larger societies, East Asians have relied on a lesser sense of self to create impersonal forms of sociality that can extend beyond the circle of close kin. More emphasis is placed on holistic attention, on social happiness rather than personal happiness, and on suspension of self-interest. Conversely, there is less emphasis on self-expression, self-esteem, and self-efficacy (Kitayama et al., 2014). In sum, large societies are built on the principle that selflessness within the family is extended to society as a whole. This principle was articulated by the Chinese philosopher Mencius: take care of your aged parents first and then extend that care to the elderly in general; take care of your children first and then extend that care to others' children (Bedford \& Hwang, 2003).

This mindset was particularly favored by rice cultivation, which requires community planning of water use and community construction of irrigation networks. Talhelm et al. (2014) examined adjacent districts in China and found 
much less individualism in people from rice-growing districts than in those from wheat-growing ones. This pattern held true even for urban residents who had never lived on a farm and were linked to rice or wheat cultivation only by ancestry.

All forms of Asian rice come from a single domestication event that occurred 13,500 to 8200 years ago in China among pre-Austronesian and early Hmong-Mien farmers of the Yangtze River basin (Molina et al., 2011). Between 6000 and 5000 years ago, this crop spread north to the millet-farming Sino-Tibetan peoples (Fuller, 2011). The latter seemed a better fit for the possibilities of rice cultivation, perhaps because they had a more suitable mindset. Over successive generations, they would become an even better fit as their mindset coevolved with the new means of subsistence.

The importance of rice in East Asia may explain why East Asians became more collectivistic than Northwest Europeans. In both groups, social orientation can be estimated from the prevalence of alleles at 5-HTTLPR and OXTR. These genes are "weathervanes" that show us which form of social orientation has been favored, and in each case East Asians more often have the alleles associated with a collectivistic orientation (Chiao \& Blizinsky, 2010; Luo \& Han, 2014).

There are also differences in empathy. Today, this trait is as well developed in East Asians as in Northwest Europeans, if not more so, but the two groups differ in the relative importance of cognitive empathy versus affective empathy. In a study of Chinese adults, Li et al. (2019) found that cognitive empathy, rather than affective empathy, significantly predicted altruistic sharing. This was the reverse of findings from Western populations. The authors concluded: "There might be cultural differences in the relations between empathy and altruism due to different levels of empathy between Western and Asian individuals." Siu and Shek (2005) noted that their Chinese participants had trouble distinguishing between the two forms of empathy: "Chinese people might not perceive the items from the two dimensions as too different in nature." In a review of his research and that of others, Atkins (2014) concluded that empathy was more cognitive and less affective in East Asian subjects. When viewing a person suffering physical or social pain, they showed less negative affect than did British subjects. Differences in empathic concern also explained differences in donating between the two groups.

So which form is better? Affective or cognitive? The question has no single answer because the same form may be better in one situation and worse in another. Affective empathy is the worse of the two when it releases so much emotion that clear thinking becomes impossible:

Thus, it is possible that being in a highly emotionally empathic state may cloud the ability to accurately infer the emotions of a target due to the heightened emotions experienced in response to the suffering of another. In line with this reasoning, East Asians' lower level of emotional involvement might have freed cognitive resources to allow them to more accurately infer the emotions of targets. (Atkins, 2014) 
On the other hand, cognitive empathy may be the worse of the two if the target is vulnerable to abuse, especially if the abuser is a psychopath who understands the target's feelings without actually experiencing them (Prado et al., 2017). The resulting harm will affect society as a whole by making everyone less trustful of each other. This outcome might be prevented if concern for others is learned and enforced as a shared collective value.

\section{Conclusion}

Northwest Europeans and East Asians dealt with the large society problem in ways that are similar in some respects and different in others. Both groups adapted to a larger social environment by becoming more empathetic toward non-kin and more susceptible to universal social norms. Northwest Europeans became more individualistic while acquiring stronger internal controls of behavior (affective empathy, guilt proneness). East Asians became more collectivistic while acquiring stronger internal controls (cognitive empathy) and stronger external controls (shaming, family-community surveillance, inculcation of normative behavior).

In these two cases, as in many others, solutions were put together from adaptations to earlier circumstances. Evolution does not anticipate future use. A trait may evolve for one use and later prove to be better for another. This explains why, counter-intuitively, a population may move into a very different environment and displace the original inhabitants, who nonetheless had been adapting to that environment for a longer time. The incoming population has a pre-existing advantage that is now even more advantageous.

If we look at the populations that have gone the farthest in solving the large society problem, we find that they were not the first to go down that path; however, they seemed to possess certain advantages that helped them go farther. In Europe, the peoples of the Northwest eventually went the farthest, yet it was not until the late Middle Ages that they began to overtake the civilizations of the Mediterranean. In East Asia, we similarly find that non-Chinese peoples had pioneered rice cultivation-the agricultural basis of China's dominance.

Finally, although the transition from hunting and gathering to farming was a key step in cultural evolution, there were equally important steps within each means of subsistence. Northwest Europeans dealt with the large society problem as Mesolithic fisher-hunter-gatherers adapting to semi-sedentary coastal communities. East Asians did so as Neolithic farmers adapting to intensive rice cultivation. Both groups, in turn, had been shaped by earlier adaptations during the Upper Paleolithic to the Ice Age environment of northern Eurasia (Frost, 2019).

\section{Acknowledgements}

This subject first caught my interest in the early 1990s through an exchange of 
letters with Kevin MacDonald in the pages of Ethology and Sociobiology. I wished to write a full-length paper and began reading the literature on the links between family structure, behavior, and psychology, particularly Seccombe's work A Millennium of Family Change. My project remained a slowly growing pile of photocopies for two decades. Meanwhile, between 2011 and 2016, a blogger, hbd chick, wrote extensively on the subject. Her views differ from mine, particularly in her belief that the Western European Marriage Pattern was a product of Catholicism and manorialism. In this, her thinking is closer to that of Jonathan Schulz. While not influencing my thinking, she has done much to promote understanding of the subject.

\section{Conflicts of Interest}

The author declares no conflicts of interest regarding the publication of this paper.

\section{References}

Ahern, F. M., Johnson, R. C., Wilson, J. R., McClearn, G. E., \& Vandenberg, S. G. (1982). Family Resemblances in Personality. Behavior Genetics, 12, 261-280. https://doi.org/10.1007/BF01067847

Anacker, K., Enge, S., Reif, A., Lesch, K.-P., \& Strobel, A. (2013). Dopamine D4 Receptor Gene Variation Impacts Self-Reported Altruism. Molecular Psychiatry, 18, 402-403. https://doi.org/10.1038/mp.2012.49

Atkins, D. (2014). The Role of Culture in Empathy: The Consequences and Explanations of Cultural Differences in Empathy at the Affective and Cognitive Levels. $\mathrm{PhD}$ Thesis, Canterbury: University of Kent. https://kar.kent.ac.uk/47970/

Baez, S., Flichtentrei, D., Prats, M., Mastandueno, R., García, A. M., Cetkovich, M., \& Ibáñez, A. (2017). Men, Women...Who Cares? A Population-Based Study on Sex Differences and Gender Roles in Empathy and Moral Cognition. PLoS ONE, 12, e0179336. https://doi.org/10.1371/journal.pone.0179336

Baker, B. S., Taylor, B. J., \& Hall, J. C. (2001). Are Complex Behaviors Specified by Dedicated Regulatory Genes? Reasoning from Drosophila. Cell, 105, 13-24.

https://doi.org/10.1016/S0092-8674(01)00293-8

Baron-Cohen, S., \& Wheelwright, S. (2004). The Empathy Quotient: An Investigation of Adults with Asperger Syndrome or High Functioning Autism, and Normal Sex Differences. Journal of Autism and Developmental Disorders, 34, 163-175. https://doi.org/10.1023/B:JADD.0000022607.19833.00

Bedford, O., \& Hwang, K.-K. (2003). Guilt and Shame in Chinese Culture: A Cross-Cultural Framework from the Perspective of Morality and Identity. Journal for the Theory of Social Behavior, 33, 127-144. https://doi.org/10.1111/1468-5914.00210

Belfer, I., Buzas, B., Hipp, H., Phillips, G., Taubman, J., Lorincz, I., Evans, C., Lipsky, R. H., Enoch, M. A., Max, M. B., \& Goldman, D. (2005). Haplotype-Based Analysis of alpha 2A, 2B, and 2C Adrenergic Receptor Genes Captures Information on Common Functional Loci at Each Gene. Journal of Human Genetics, 50, 12-20. https://doi.org/10.1007/s10038-004-0211-y

Berman, H. J. (1974). The Interaction of Law and Religion. Nashville, TN: Abingdon Press. 
Bircher, J., Kotyuk, E., Fulop, M., Vereczkei, A., Ronai, Z., Varga, K., \& Szekely, A. (2019). Gene-Sex Interaction in Hypercompetitive Attitude Suggests Beneficial Effect of the DRD4 7-Repeat Allele in Adaptation. Neuropsychopharmacologia Hungarica, 21, 47-58.

Burris, C. T., \& Rempel, J. K. (2012). The Crystal Globe: Emotional Empathy and the Transformation of Self. Consciousness and Cognition, 21, 1526-1532.

https://doi.org/10.1016/j.concog.2012.06.002

Bybee, J. (1998). The Emergence of Gender Differences in Guilt during Adolescence. In J. Bybee (Ed.), Guilt and Children (pp. 114-125). San Diego, CA: Academic Press. https://doi.org/10.1016/B978-012148610-5/50006-0

Bybee, J., \& Quiles, Z. N. (1998). Guilt and Mental Health. In J. Bybee (Ed.), Guilt and Children (pp. 270-291). San Diego, CA: Academic Press. https://doi.org/10.1016/B978-012148610-5/50014-X

Bybee, J., Zigler, E., Berliner, D., \& Merisca, R. (1996). Guilt, Guilt-Evoking Events, Depression, and Eating Disorders. Current Psychology, 15, 113-127.

https://doi.org/10.1007/BF02686944

Caesar, J. (1915). De Bello Gallico \& Other Commentaries of Caius Julius Caesar (Translated by W. A. Macdevitt). London: J.M. Dent.

Caspi, A., Sugden, K., Moffitt, T. E., Taylor, A., Craig, I. W., Harrington, H., McClay, J., Mill, J., Martin, J., Braithwaite, A., \& Poulton, R. (2003). Influence of Life Stress on Depression: Moderation by a Polymorphism in the 5-HTT Gene. Science, 301, 386-389. https://psycnet.apa.org/doi/10.1126/science.1083968 https://doi.org/10.1126/science.1083968

Cattell, R. B., Klein, T. W., Schuerger, J. M., \& Kameoka, V. (1981). Application of the MAVA Design and the OSES Analysis Method to Determine the Heritability of the Clinical Personality Factors: Guilt Proneness, O; Parmia, H; and Ergic Tension, $\mathrm{Q}_{4}$. Personality Study \& Group Behaviour, 1, 1-22.

Chakrabarti, B., \& Baron-Cohen, S. (2013). Understanding the Genetics of Empathy and the Autistic Spectrum. In S. Baron-Cohen, H. Tager-Flusberg, \& M. Lombardo (Eds.), Understanding Other Minds: Perspectives from Developmental Social Neuroscience (pp. 327-342). Oxford: Oxford University Press.

Chen, C., Moyzis, R. K., Lei, X., Chen, C., \& Dong, Q. (2016). The Encultured Genome: Molecular Evidence for Recent Divergent Evolution in Human Neurotransmitter Genes. In J. Y. Chiao, S.-C. Li, R. Seligman, \& R. Turner (Eds.), The Oxford Handbook of Cultural Neuroscience (pp. 315-336). New York, NY: Oxford University Press. https://doi.org/10.1093/oxfordhb/9780199357376.013.22

Chiao, J. Y., \& Blizinsky, K. D. (2010). Culture-Gene Coevolution of Individualism-Collectivism and the Serotonin Transporter Gene. Proceedings of the Royal Society B: Biological Sciences, 277, 529-537. https://doi.org/10.1098/rspb.2009.1650

Christov-Moore, L., Simpson, E. A., Coudé, G., Grigaityte, K., Iacoboni, M., \& Ferrari, P. F. (2014). Empathy: Gender Effects in Brain and Behavior. Neuroscience \& Biobehavioral Reviews, 46, 604-627. https://doi.org/10.1016/j.neubiorev.2014.09.001

Cialdini, R. B., Brown, S. L., Lewis, B. P., Luce, C., \& Neuberg, S. L. (1997). Reinterpreting the Empathy-Altruism Relationship: When One into One Equals Oneness. Journal of Personality and Social Psychology, 73, 481-494. https://doi.org/10.1037/0022-3514.73.3.481

Cochran, G., \& Harpending, H. (2009). The 10,000 Year Explosion: How Civilization Accelerated Human Evolution. New York, NY: Basic Books. 
Cousijn, H., Rijpkema, M., Qin, S., van Marle, H. J. F., Franke, B., Herman, E. J., van Wingen, G., \& Fernández, G. (2010). Acute Stress Modulates Genotype Effects on Amygdala Processing in Humans. Proceedings of the National Academy of Sciences of the United States of America, 107, 9867-9872. https://doi.org/10.1073/pnas.1003514107

Das, G. (2002). India Unbound. The Social and Economic Revolution from Independence to the Global Information Age. New York, NY: Anchor Books.

de Quervain, D. J.-F., Kolassa, I.-T., Ertl, V., Onyut, P. L., Neuner, F., Elbert, T., \& Papassotiropoulos, A. (2007). A Deletion Variant of the a2b-Adrenoceptor Is Related to Emotional Memory in Europeans and Africans. Nature Neuroscience, 10, 1137-1139. https://doi.org/10.1038/nn1945

Decety, J., Meidenbauer, K. L., \& Cowell, J. M. (2017). The Development of Cognitive Empathy and Concern in Preschool Children: A Behavioral Neuroscience Investigation. Developmental Science, 21, e12570. https://doi.org/10.1111/desc.12570

Doan, R. N., Bae, B-I., Cubelos, B., Chang, C., Hossain, A. A., Al-Saad, S., Mukaddes, N. M., Oner, O., Al-Saffar, M., Balkhy, S., Gascon, G. G., THMCA, Nieto, M., \& Walsh, C. A. (2016). Mutations in Human Accelerated Regions Disrupt Cognition and Social Behavior. Cell, 167, 341-354.e12. https://doi.org/10.1016/j.cell.2016.08.071

Dryburgh, N. S. J., \& Vachon, D. D. (2019). Relating Sex Differences in Aggression to Three Forms of Empathy. Personality and Individual Differences, 151, Article ID: 109526. https://doi.org/10.1016/j.paid.2019.109526

Eaves, L., Heath, A., Martin, N., Maes, H., Neale, M. C., Kendler, K., Kirk, K., \& Corey, L. (1999). Comparing the Biological and Cultural Inheritance of Personality and Social Attitudes in the Virginia 30,000 Study of Twins and Their Relatives. Twin Research and Human Genetics, 2, 62-80. https://doi.org/10.1375/twin.2.2.62

Else-Quest, N. M., Higgins, A., Allison, C., \& Morton, L. C. (2012). Gender Differences in Self-Conscious Emotional Experience: A Meta-Analysis. Psychological Bulletin, 138, 947-981. https://doi.org/10.1037/a0027930

Englander, Z. A., Haidt, J., \& Morris, J. P. (2012). Neural Basis of Moral Elevation Demonstrated through Inter-Subject Synchronization of Cortical Activity during Free-Viewing. PLoS ONE, 7, e39384. https://doi.org/10.1371/journal.pone.0039384

Fenstermacher, S. K., \& Saudino, K. J. (2016). Exploring Links among Imitation, Mental Development, and Temperament. Infancy, 21, 536-559.

https://doi.org/10.1111/infa.12132

Fridman, A., van IJzendoorn, M. H., Sagi-Schwartz, A., \& Bakermans-Kranenburg, M. J. (2012). Genetic Moderation of Cortisol Secretion in Holocaust Survivors: A Pilot Study on the Role of ADRA2B. International Journal of Behavioral Development, 36, 79-84. https://doi.org/10.1177/0165025411406859

Frost, P. (2010). The Roman State and Genetic Pacification. Evolutionary Psychology, 8, 376-389. https://doi.org/10.1177/147470491000800306

Frost, P. (2017). The Hajnal Line and Gene-Culture Coevolution in Northwest Europe. Advances in Anthropology, 7, 154-174. https://doi.org/10.4236/aa.2017.73011

Frost, P. (2019). The Original Industrial Revolution. Did Cold Winters Select for Cognitive Ability? Psych, 1, 166-181. https://doi.org/10.3390/psych1010012

Frost, P., \& Harpending, H. (2015). Western Europe, State Formation, and Genetic Pacification. Evolutionary Psychology, 13, 230-243.

https://doi.org/10.1177/147470491501300114

Fuller, D. Q. (2011). Pathways to Asian Civilizations: Tracing the Origins and Spread of Rice and Rice Cultures. Rice, 4, 78-92. https://doi.org/10.1007/s12284-011-9078-7 
Grøn, O. (2003). Mesolithic Dwelling Places in South Scandinavia: Their Definition and Social Interpretation. Antiquity, 77, 685-708.

https://doi.org/10.1017/S0003598X00061640

Hajnal, J. (1965). European Marriage Pattern in Perspective. In D. V. Glass, \& D. E. C. Eversley (Eds.), Population in History. Essays in Historical Demography (pp. 101-143). Chicago, Illinois: Aldine Publishing Company.

Hallam, H. E. (1985). Age at First Marriage and Age at Death in the Lincolnshire Fenland, 1252-1478. Population Studies, 39, 55-69. https://doi.org/10.1080/0032472031000141276

Harpending, H., \& Cochran, G. (2002). In Our Genes. Proceedings of the National Academy of Sciences of the United States of America, 99, 10-12. https://doi.org/10.1073/pnas.012612799

Hartman, M. S. (2004). The Household and the Making of History. A Subversive View of the Western Past. Cambridge: Cambridge University Press. https://doi.org/10.1017/CBO9780511818134

Hawks, J., Wang, E. T., Cochran, G. M., Harpending, H. C., \& Moyzis, R. K. (2007). Recent Acceleration of Human Adaptive Evolution. Proceedings of the National Academy of Sciences of the United States of America, 104, 20753-20758. https://doi.org/10.1073/pnas.0707650104

Hoffman, M. L. (1977). Sex Differences in Empathy and Related Behaviors. Psychological Bulletin, 84, 712-722. https://psycnet.apa.org/doi/10.1037/0033-2909.84.4.712 https://doi.org/10.1037/0033-2909.84.4.712

ICA (2020). Research Themes-Marriage Patterns. Institutions for Collective Action. http://www.collective-action.info/_THE_MarriagePatterns_EMP

Ishii, M., Katoh, H., Kurihara, T., Saguchi, K., Shimizu, S., \& Kawamura, M. (2015). Catechol-O-Methyl Transferase Gene Polymorphisms in Japanese Patients with Medication Overuse Headaches. JSM Genetics and Genomics, 2, 1-4.

Jiang, Y., Bachner-Melman, R., Chew, S. H., \& Ebstein, R. P. (2015). Dopamine D4 Receptor Gene and Religious Affiliation Correlate with Dictator Game Altruism in Males and Not Females: Evidence for Gender-Sensitive Gene $\times$ Culture Interaction. Frontiers in Neuroscience, 9, 338. https://doi.org/10.3389/fnins.2015.00338

Kanai, R., Feilden, T., Firth, C., \& Rees, G. (2011). Political Orientations Are Correlated with Brain Structure in Young Adults. Current Biology, 21, 677-680.

https://doi.org/10.1016/j.cub.2011.03.017

Kim, H. S., Sherman, D. K., Mojaverian, T., Sasaki, J. Y., Park, J., Suh, E. M., \& Taylor, S. E. (2011). Gene-Culture Interaction: Oxytocin Receptor Polymorphism (OXTR) and Emotion Regulation. Social Psychological and Personality Science, 2, 665-672. https://doi.org/10.1177/1948550611405854

Kitayama, S., King, A., Yoon, C., Tompson, S., Huff, S., \& Liberzon, I. (2014). The Dopamine D4 Receptor Gene (DRD4) Moderates Cultural Difference in Independent versus Interdependent Social Orientation. Psychological Science, 25, 1169-1177. https://doi.org/10.1177/0956797614528338

Langford, D. J., Tuttle, A. H., Brown, K., Deschenes, S., Fischer, D. B., Mutso, A., Root, K. C., Sotocinal, S. G., Stern, M. A., Mogil, J. S., \& Sternberg, W. F. (2010). Social Approach to Pain in Laboratory Mice. Social Neuroscience, 5, 163-170. https://doi.org/10.1080/17470910903216609

Lebra, T. S. (1971). The Social Mechanism of Guilt and Shame: The Japanese Case. Anthropological Quarterly, 44, 241-255. https://doi.org/10.2307/3316971 
Li, Z., Yu, J., \& Zhu, L. (2019). Associations between Empathy and Altruistic Sharing Behavior in Chinese Adults. The Journal of General Psychology, 146, 1-16. https://doi.org/10.1080/00221309.2018.1510826

Liu, J., Qiao, X., Dong, F., \& Raine, A. (2018). The Chinese Version of the Cognitive, Affective, and Somatic Empathy Scale for Children: Validation, Gender Invariance and Associated Factors. PLOS ONE, 13, e0195268.

https://doi.org/10.1371/journal.pone.0195268

Loewen, P. J., Dawes, C. T., Mazar, N., Johannesson, M., Keollinger, P., \& Magnusson, P. K. E. (2013). The Heritability of Moral Standards for Everyday Dishonesty. Journal of Economic Behavior \& Organization, 93, 363-366. https://doi.org/10.1016/j.jebo.2013.05.001

Lucht, M. J., Barnow, S., Sonnenfeld, C., Rosenberger, A., Grabe, H. J., Schroeder, W., Völzke, H., Freyberger, H. J., Herrmann, F. H., Kroemer, H., \& Rosskopf, D. (2009). Associations between the Oxytocin Receptor Gene (OXTR) and Affect, Loneliness and Intelligence in Normal Subjects. Progress in Neuro-Psychopharmacology and Biological Psychiatry, 33, 860-866. https://doi.org/10.1016/j.pnpbp.2009.04.004

Luman, A. (2019). Deceptive Behaviour Modulation by Feedback Strategies and by Inhibitory Potential of the Gene GABRA2 (rs279858). University of Tartu, Faculty of Social Sciences, Institute of Psychology.

https://web-proxy.io/proxy/dspace.ut.ee/handle/10062/65300

Luo, S., \& Han, S. (2014). The Association between an Oxytocin Receptor Gene Polymorphism and Cultural Orientations. Culture and Brain, 2, 89-107. https://doi.org/10.1007/s40167-014-0017-5

Luo, S., Ma, Y., Liu, Y., Li, B., Wang, C., Shi, Z., Li, X., Zhang, W., Rao, Y., \& Han, H. (2015). Interaction between Oxytocin Receptor Polymorphism and Interdependent Culture Values on Human Empathy. Social Cognitive and Affective Neuroscience, 10, 1273-1281. https://doi.org/10.1093/scan/nsv019

MacDonald, K. (2019a). Individualism and the Western Liberal Tradition: Evolutionary Origins, History, and Prospects for the Future. Amazon.

MacDonald, K. (2019b). Can Western Church Influence Explain Western Individualism? Comment on "The Church, Intensive Kinship, and Global Psychological Variation," by Jonathan F. Schulz et al. Preprint.

Marsh, A. A., Stoycos, S. A., Brethel-Haurwitz, K. M., Robinson, P., VanMeter, J. W., \& Cardinale, E. M. (2014). Neural and Cognitive Characteristics of Extraordinary Altruists. Proceedings of the National Academy of Sciences of the United States of America, 111, 15036-15041. https://doi.org/10.1073/pnas.1408440111

McCann, C. A. (2010). Transgressing the Boundaries of Holiness: Sexual Deviance in the Early Medieval Penitential Handbooks of Ireland, England and France 500-1000. Theses, South Orange, NJ: Seton Hall University. https://scholarship.shu.edu/theses/76

Medrano, J. D. (2010). Interpersonal Trust. World Values Survey Archive. http://www.jdsurvey.net/jds/jdsurveyMaps.jsp?Idioma=I\&SeccionTexto=0404\&NOID $=104$

Melchers, M., Montag, C., Reuter, M., Spinath, F. M., \& Hahn, E. (2016). How Heritable Is Empathy? Differential Effects of Measurement and Subcomponents. Motivation and Emotion, 40, 720-730. https://doi.org/10.1007/s11031-016-9573-7

Molina, J., Sikora, M., Garud, N., Flowers, J. M., Rubinstein, S., Reynolds, A., Huang, P., Jackson, S., Schaal, B. A., Bustamante, C. D., Boyko, A. R., \& Purugganan, M. D. (2011). Molecular Evidence for a Single Evolutionary Origin of Domesticated Rice. Proceedings of the National Academy of Sciences of the United States of America, 108, 
8351-8356. https://doi.org/10.1073/pnas.1104686108

Mulerova, T. A., Yankin, A. Y., Rubtsova, Y. V., Kuzmina, A. A., Orlov, P. S., Tatarnikova, N. P., Maksimov, V. N., Voevoda, M. I., \& Ogarkov, M. Y. (2015). Association of ADRA2B Polymorphism with Risk Factors for Cardiovascular Diseases in Native Population of Mountain Shoria. Bulletin of Siberian Medicine, 14, 29-34.

Peled-Avron, L., Perry, A., \& Shamay-Tsoory, S. G. (2016). The Effect of Oxytocin on the Anthropomorphism of Touch. Psychoneuroendocrinology, 66, 159-165. https://doi.org/10.1016/j.psyneuen.2016.01.015

Prado, C. E., Treeby, M. S., Rice, S. M., \& Crowe, S. F. (2017). Facial Emotion Recognition, Guilt and Sub-Clinical Psychopathic Traits: An Exploration of Mediation Effects. Motivation and Emotion, 41, 636-645. https://doi.org/10.1007/s11031-017-9628-4

Price, T. D. (1991). The Mesolithic of Northern Europe. Annual Review of Anthropology, 20, 211-233. https://www.jstor.org/stable/2155800 https://doi.org/10.1146/annurev.an.20.100191.001235

Radcliffe-Brown, A. R. (1987 [1950]). Introduction. In A. R. Radcliffe-Brown, \& D. Forde (Eds.), African Systems of Kinship and Marriage (pp. 1-85). New York, NY: Routledge.

Rose, D. C. (2019). Why Culture Matters Most. New York, NY: Oxford University Press.

Sasaki, J. Y., Kim, H. S., Mojaverian, T., Kelley, L. D. S., Park, I. Y., \& Janušonis, S. (2013). Religion Priming Differentially Increases Prosocial Behavior among Variants of the Dopamine D4 Receptor (DRD4) Gene. Social Cognitive and Affective Neuroscience, 8, 209-215. https://doi.org/10.1093/scan/nsr089

Schreiber, D., Fonzo, G., Simmons, A. N., Dawes, C. T., Flagan, T., Fowler, J. H., \& Paulus, M. P. (2013). Red Brain, Blue Brain: Evaluative Processes Differ in Democrats and Republicans. PLoS ONE, 8, e52970. https://doi.org/10.1371/journal.pone.0052970

Schroeder, K. B., Asherson, P., Blake, P. R., Fenstermacher, S. K., \& Saudino, K. J. (2016). Variant at Serotonin Transporter Gene Predicts Increased Imitation In Toddlers: Relevance to the Human Capacity for Cumulative Culture. Biology Letters, 12, Article ID: 20160106. https://doi.org/10.1098/rsbl.2016.0106

Schulz, J. F., Bahrami-Rad, D., Beauchamp, J. P., \& Henrich, J. (2019). The Church, Intensive Kinship, and Global Psychological Variation. Science, 366, eaau5141. https://doi.org/10.1126/science.aau5141

Seccombe, W. (1992). A Millennium of Family Change. Feudalism to Capitalism in Northwestern Europe. London: Verso.

Shen, Q., Teo, M., Winter, E., Hart, E., Chew, S. H., \& Ebstein, R. P. (2016). To Cheat or Not to Cheat: Tryptophan Hydroxylase 2 SNP Variants Contribute to Dishonest Behavior. Frontiers in Behavioral Neuroscience, 10, 82. https://doi.org/10.3389/fnbeh.2016.00082

Siu, A. M. H., \& Shek, D. T. L. (2005). Validation of the Interpersonal Reactivity Index in a Chinese Context. Research on Social Work Practice, 15, 118-126. https://doi.org/10.1177/1049731504270384

Small, K. M., \& Liggett, S. B. (2001). Identification and Functional Characterization of $\alpha_{2}$-Adrenoceptor Polymorphisms. Trends in Pharmacological Sciences, 22, 471-477. https://doi.org/10.1016/S0165-6147(00)01758-2

Suzuki, N., Matsunaga, T., Nagasumi, K., Yamamura, T., Shihara, N., Moritani, T., Ue, H., Fukushima, M., Tamon, A., Seino, Y., Tsuda, K., \& Yasuda, K. (2003). $\alpha_{2 B}$-Adrenergic Receptor Deletion Polymorphism Associates with Autonomic Nervous System Activity in Young Healthy Japanese. The Journal of Clinical Endocrinology \& Metabolism, 88, 1184-1187. https://doi.org/10.1210/jc.2002-021190 
Szentágotai-Tatar, A., Chis, A., Vulturar, R., Dobrean, A., Cândea, D. M., \& Miu, A. C. (2015). Shame and Guilt-Proneness in Adolescents: Gene-Environment Interactions. PLoS ONE, 10, e0134716. https://doi.org/10.1371/journal.pone.0134716

Tacitus (1970). Agricola, Germania, Dialogus. Loeb Classical Library (Translated by M. Hutton \& W. Peterson). Cambridge, MA: Harvard University Press.

Talhelm, T., Zhang, X., Oishi, S., Shimin, C., Duan, D., Lan, X., \& Kitayama, S. (2014). Large-Scale Psychological Differences within China Explained by Rice versus Wheat Agriculture. Science, 344, 603-607. https://doi.org/10.1126/science.1246850

Tan, C. (2017). Confucianism and Education. In Oxford Research Encyclopedias. Oxford: Oxford University Press. https://doi.org/10.1093/acrefore/9780190264093.013.226

Tangney, J. P., Stuewig, J., Mashek, D., \& Hastings, M. (2011). Assessing Jail Inmates' Proneness to Shame and Guilt: Feeling Bad about the Behavior or the Self? Criminal Justice and Behavior, 38, 710-734. https://doi.org/10.1177/0093854811405762

Tangney, J. P., Wagner, P., \& Gramzow, R. (1992). Proneness to Shame, Proneness to Guilt, and Psychopathology. Journal of Abnormal Psychology, 101, 469-478.

https://psycnet.apa.org/doi/10.1037/0021-843X.101.3.469 https://doi.org/10.1037/0021-843X.101.3.469

Toccaceli, V., Fagnani, C., Eisenberg, N., Alessandri, G., Vitale, A., \& Stazi, M. A. (2018). Adult Empathy: Possible Gender Differences in Gene-Environment Architecture for Cognitive and Emotional Components in a Large Italian Twin Sample. Twin Research and Human Genetics, 21, 214-226. https://doi.org/10.1017/thg.2018.19

Todd, R. M., \& Anderson, A. K. (2009). The Neurogenetics of Remembering Emotions Past. Proceedings of the National Academy of Sciences of the United States of America, 106, 18881-18882. https://doi.org/10.1073/pnas.0910755106

Todd, R. M., Ehlers, M. R., Muller, D. J., Robertson, A., Palombo, D. J., Freeman, N., Levine, B., \& Anderson, A. K. (2015). Neurogenetic Variations in Norepinephrine Availability Enhance Perceptual Vividness. The Journal of Neuroscience, 35, 6506-6516. https://doi.org/10.1523/JNEUROSCI.4489-14.2015

Tompson, S. H., Huff, S. T., Yoon, C., King, A., Liberzon, I., \& Kitayama, S. (2018). The Dopamine D4 Receptor Gene (DRD4) Modulates Cultural Variation in Emotional Experience. Culture and Brain, 6, 118-129. https://doi.org/10.1007/s40167-018-0063-5

Treeby, M. S., Prado, C., Rice, S. M., \& Crowe, S. F. (2016). Shame, Guilt, and Facial Emotion Processing: Initial Evidence for a Positive Relationship between Guilt-Proneness and Facial Emotion Recognition Ability. Cognition and Emotion, 30, 1504-1511. https://doi.org/10.1080/02699931.2015.1072497

Trivers, R. L. (1971). The Evolution of Reciprocal Altruism. Quarterly Review of Biology, 46, 35-57. https://doi.org/10.1086/406755

van Honk, J., Schutter, D. J., Bos, P. A., Kruijt, A.-W., Lentjes, E. G., \& Baron-Cohen, S. (2011). Testosterone Administration Impairs Cognitive Empathy in Women Depending on Second-to-Fourth Digit Ratio. Proceedings of the National Academy of Sciences of the United States of America, 108, 3448-3452.

https://doi.org/10.1073/pnas.1011891108

Vellante, M., Baron-Cohen, S., Melis, M., Marrone, M., Petretto, D. R., Masala, C., \& Preti, A. (2013). The "Reading the Mind in the Eyes" Test: Systematic Review of Psychometric Properties and a Validation Study in Italy. Cognitive Neuropsychiatry, 18, 326-354. https://doi.org/10.1080/13546805.2012.721728

Weisman, O., Pelphrey, K. A., Leckman, J. F., Feldman, R., Lu, Y., Chong, A., Chen, Y., Monakhov, M., Chew, S. H., \& Ebstein, R. P. (2015). The Association between 2D:4D 
Ratio and Cognitive Empathy Is Contingent on a Common Polymorphism in the Oxytocin Receptor Gene (OXTR rs53576). Psychoneuroendocrinology, 58, 23-32. https://doi.org/10.1016/j.psyneuen.2015.04.007

Witvliet, C. V., Luna, L. M. R., VanderStoep, J. L., Gonzalez, T., \& Griffin, G. D. (2020). Granting Forgiveness: State and Trait Evidence for Genetic and Gender Indirect Effects through Empathy. The Journal of Positive Psychology, 15, 390-399.

https://doi.org/10.1080/17439760.2019.1615108

Witvliet, C. V., Luna, L. R., VanderStoep, J. V., Vlisides-Henry, R. D., Gonzalez, T., \& Griffin, G. D. (2019). OXTR rs53576 Genotype and Gender Predict Trait Gratitude. The Journal of Positive Psychology, 14, 417-426. https://doi.org/10.1080/17439760.2018.1460689

Young, P. A., Eaves, L. J., \& Eysenck, H. J. (1980). Intergenerational Stability and Change in the Causes of Variation in Personality. Personality and Individual Differences, 1, 35-55. https://doi.org/10.1016/0191-8869(80)90004-5

Zahn-Waxler, C., \& Robinson, J. (1995). Empathy and Guilt: Early Origins of Feelings of Responsibility. In J. P. Tangney, \& K. W. Fisher (Eds.), Self-Conscious Emotions: The Psychology of Shame, Guilt, Embarrassment, and Pride (pp. 143-173). New York, NY: Guilford Press.

Zhang, H., Li, X., Huang, J., Li, Y., Thijs, L., Wang, Z., Lu, X., Cao, K., Xie, S., Staessen, J. A., \& Wang, J.-G. (2005). Cardiovascular and Metabolic Phenotypes in Relation to the ADRA2B Insertion/Deletion Polymorphism in a Chinese Population. Journal of Hypertension, 23, 2201-2207. https://doi.org/10.1097/01.hjh.0000189869.48290.91

Zhong, S., Israel, S., Shalev, I., Xue, H., Ebstein, R. P., \& Chew, S. H. (2010). Dopamine D4 Receptor Gene Associated with Fairness Preference in Ultimatum Game. PLoS ONE, 5, e13765. https://doi.org/10.1371/journal.pone.0013765

Zvelebil, M., \& Dolukhanov, P. (1991). The Transition to Farming in Eastern and Northern Europe. Journal of World Prehistory, 5, 233-278.

https://doi.org/10.1007/BF00974991 